Cahiers $d u$ MONDE RUSSE

\section{Cahiers du monde russe}

Russie - Empire russe - Union soviétique et États indépendants

$56 / 2-3 \mid 2015$

Communiquer en URSS et en Europe socialiste

\title{
The Conflicted Origins of Soviet Visual Media
}

Painting, Photography, and Communication in Russia, 1925-1932

Les débats à l'origine des média visuels soviétiques : peinture, photographie et communication en Russie, 1925-1932

\section{Angelina Lucento}

\section{(2) OpenEdition}

\section{Journals}

Édition électronique

URL : http://journals.openedition.org/monderusse/8191

DOI : 10.4000/monderusse.8191

ISSN : $1777-5388$

\section{Éditeur}

Éditions de l'EHESS

Édition imprimée

Date de publication : 17 avril 2015

Pagination : 401-428

ISBN : 978-2-7132-2476-8

ISSN : $1252-6576$

\section{Référence électronique}

Angelina Lucento, «The Conflicted Origins of Soviet Visual Media », Cahiers du monde russe [En ligne], 56/2-3 | 2015, mis en ligne le 17 novembre 2019, Consulté le 22 avril 2019. URL : http:// journals.openedition.org/monderusse/8191; DOI : 10.4000/monderusse.8191

Ce document a été généré automatiquement le 22 avril 2019.

(c) École des hautes études en sciences sociales 


\title{
The Conflicted Origins of Soviet Visual Media
}

\author{
Painting, Photography, and Communication in Russia, 1925-1932 ${ }^{1}$ \\ Les débats à l'origine des média visuels soviétiques : peinture, photographie et \\ communication en Russie, 1925-1932
}

\section{Angelina Lucento}

1 In his 1925 review of Revolution, Everyday Life, and Labor, the seventh exhibition of the Association of Artists of Revolutionary Russia (AKhRR), Anatolii Lunacharskii wrote a sharp critique of the photographic medium. Photography, he argued, in its pervasiveness was beginning to ruin painting, a medium, which he contended was vital to the development of socialism. ${ }^{2}$

The general impression, I repeat, is such that we often get instead of a painting a good photograph colored in a more or less satisfactory manner.

It is imperative that the artist create his own picture, so that it would appear to have been conceived in his blood and nerves, so that it would be his poem, and not a reflection, like a photographic shot [emphasis in the original]. ${ }^{3}$

Most of AKhRR's figurative realist paintings disappointed Lunacharskii. He notes, however, that among the group members there is one painter, whose work does not mimic photography. Lunacharskii describes Fëdor Bogorodskii, who exhibited paintings from his series Besprizornye [Urchins] (see fig. 1, Portrait of a Homeless Boy, 1925), as an expert renderer of affect and human experience. ${ }^{4}$ Lunacharskii's discussion of the difference between a photograph as a surface that "reflects," and a figurative painting as an object that can convey emotional and corporeal sensation marked the beginning of an important shift in the ongoing public debates about the role of visual art in the development of socialism. ${ }^{5}$ Initially, these debates had focused on the question of whether the more traditional forms of art, such as painting and sculpture, were still relevant to the socialist context. The faction of modernist artists, who had designated themselves Constructivists, argued for the abandonment of these traditional forms in favor of the total movement of art into life. The members of AKhRR, on the other hand, as well as the members of other politically engaged artists' groups, such as the Society of Easel Painters 
(OST), continued to make a case for painting. ${ }^{6}$ By 1925 , however, the debates' participants had begun to focus on more specific questions, such as the question of how the prevalence of photographic images was beginning to alter the apprehension and perception of the visual. How would the new photographically mediated vision impact the development of socialism?

Fig. 1 - Fëdor Bogorodskii, “Portrait of a Homeless Boy”. From the series “Urchins," 1925

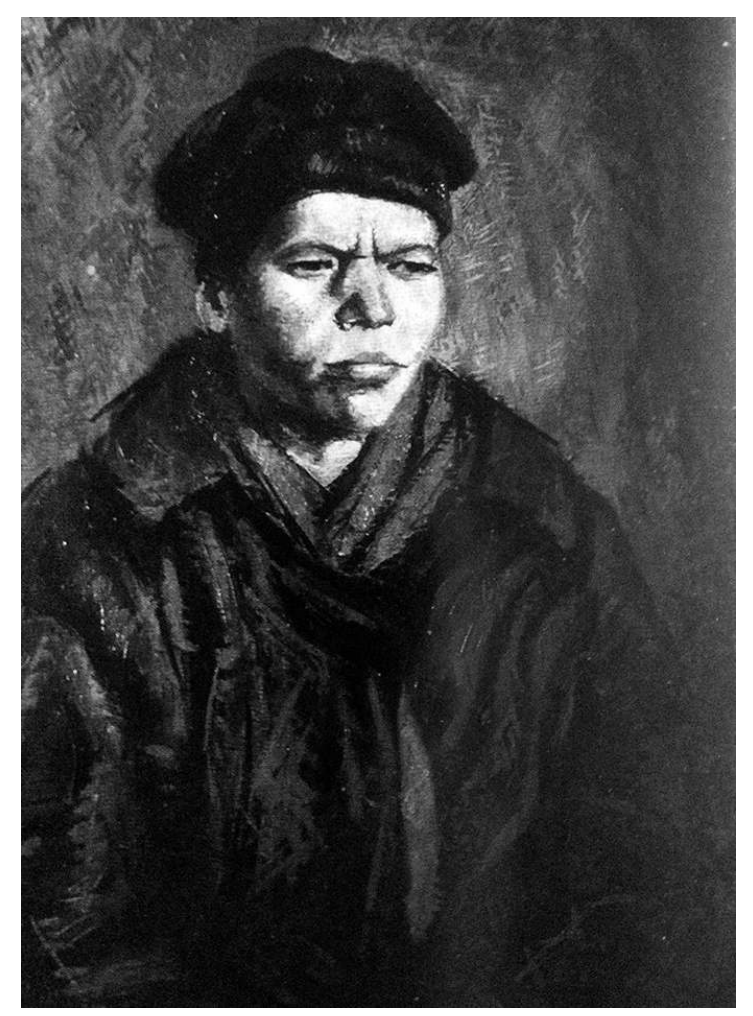

OIL ON PLYWOOD

(C) 2015, STATE RUSSIAN MUSEUM, ST. PETERSBURg

3 This essay demonstrates that the figurative realist painting that the members of AKhRR promoted became an integral aspect of early Soviet visual culture, because the participants in this new debate about photography reached an unexpected consensus. ${ }^{7}$ Representatives from the Constructivist faction, who had previously argued for the abandonment of painting, the members of OST and AKhRR, as well as several critics and theorists, including Lunacharskii, agreed that painting's vivid color and textured materiality had an effect on the spectator's experience of the visual that photography could not yet achieve. ${ }^{8}$ This impact, they further agreed, would be critical to the development of a collective society. The consensus, however, ended here. The theorists associated with the journal Lef (Levyi front iskusstv [Left front of the Arts]), which supported the Constructivists, argued for the integration of the characteristics of painting into mechanical visual media. The form of the easel, they claimed, was a dangerous relic of the market economy. The articulation of this position ignited a series of contentious debates about the role of mechanically produced visual media in the formation of the new socialist subject, which peaked during the first year of the Cultural Revolution. By 1932, the members of AKhRR and the critics and theorists who supported the work of the radical modernists reached another fragile agreement, which had a 
lasting impact on Soviet communications theory. Mechanical media, such as film and photography, were recognized as vital to both the development of social connections and collective spectatorship. Figurative painting, on the other hand, was recognized as crucial for the maintenance of the collective's awareness of the human body as an organic, rather than industrial organism. Such a corpus was considered both the site of proletarian consciousness, and the source of sensual, comradely social relations. This essay aims to open up a space for a broader understanding of the critical roles that both photography and painting played in socialist communication, as well as to contribute to the growing body of scholarship on the function of figurative realism in twentieth century visual culture. ${ }^{9}$

\section{Mediation, Materiality, and Collaboration}

4 Anatolii Lunacharskii formed a close personal and professional relationship with the economist and communications theorist Aleksandr Bogdanov well before the October Revolution. The two men studied philosophy together in Moscow, and in 1908-09 they collaborated on the development of the theory of proletarian culture at the Capri school. ${ }^{10}$ In his 1920 text, "Puti proletarskogo tvorchestva [Paths of Proletarian Creation]," Bogdanov offered a definition of proletarian, collectivist culture and described what it would achieve. "The realization of collectivism, which deepens the people's reciprocal understanding and the emotional connections between them," Bogdanov writes, "will make possible what will be incomparably, until now, the broadest and most immediate collectivism in creation, that is, the direct collaboration among many, on a mass scale." ${ }^{11}$ While Bogdanov admits that the art of the past contains previously unrecognized elements of collective collaboration and suggests that the proletarian art critic should, in his analyses, work to bring these elements to light, he also stresses that the art of the new proletarian collective will not be forged from the same materials and methods as the old, pre-revolutionary art. ${ }^{12}$ "The technical methods of the old art," Bogdanov argues, "evolved separately from the methods of the other spheres of life; the technical methods of proletarian art should consciously seek out and use material from all of these methods. For example, photography, stereography, cinema-photography, the color spectrum, phonography, etc. must find their own defined methods within the system of artistic technology as its media." ${ }^{13}$

Bogdanov considers these advanced technical methods especially appropriate for proletarian creation, because as products of the machine they can be easily standardized and rapidly produced and distributed. Standardization and accessibility would have an equalizing effect. Since the members of the new society would all be working with the same means of creation and existence, the social factors that had once distinguished and divided them would disappear. This industrially mediated equality would result in a collective social body that would be characterized by a "scientifically organized system of comradely relations, a centralized collective, founded on the utmost mobility of its elements and its groups, and a high level of psychological consistency among the working class, as the comprehensive evolution of the workers' consciousness (original emphasis)." ${ }^{14}$ Here Bogdanov argues that the workers' direct engagement with the all-encompassing means of industrial production, which constitute the substance of proletarian existence, would instill in them an elevated, yet regular consciousness. This psychological regularity would ensure that the members of the proletariat, like the component parts of a highly 
functional machine, would be compatible with one another. "Reciprocal understanding" and collaboration will be inevitable consequences of this compatibility, and will result in the formation of a social body that epitomizes "scientifically organized" rationality.

Despite their close personal and professional relationship, Lunacharskii did not agree with Bogdanov's position that industrially produced, technical means, especially photography, should become the primary means of proletarian creation. He did agree with the basic principle of Bogdanov's argument that a collective social body would be formed from compatible social connections. These connections, in his view, would "organize" the form of the collective body, giving it shape and substance as they developed. Against Bogdanov, however, Lunacharskii argued that while industrialization shaped workers, both physically and psychologically, into sleek, compatible machine-like components, the type of organization that resulted from technological mediation was not synonymous with socialist collectivism. ${ }^{15}$ A socialist collective, in his view, could only be formed through a new kind of human collaboration, which would be achieved not through cognitive homogeneity and physical compatibility, but through the sensate experience of corporeal resonance and dissonance.

7 In his writings on aesthetics, Lunacharskii defined a work of art as any object that could instigate this "poetic" dissonance-in-resonance, and thus catalyze the development of an "artistically organized" intimate and collaborative human collective, rather than a regulated, machine-like system. He began to formulate this argument in the first years of the twentieth century, when he and Bogdanov were working out their ideas about proletarian culture. In "The Tasks of Social-Democratic Artistic Creation," which was first published in 1907 and reprinted in 1924, Lunacharskii argued that the proletarian artist's first task was to "set the expectation for that broad, intimate, universal brotherhood, toward which the proletariat leads the world along the path to socialism." ${ }^{16}$ Drawing on the work of the Dutch poet and socialist activist Henriette Roland-Holst, he suggested that this expectation could be set through the use of a new poetic language, which would not only express the "feeling (chvustvo)" and "passions (strasti) that summon man to action," but would also "reveal the reasons for those actions." ${ }^{17}$ Such a method of communication would not only resonate with the proletariat, but would also beckon the members of other social classes toward a collective existence by exposing the source of the connections between them.

"Isn't it true," Lunacharskii asks rhetorically, "that the artist-socialist (now : communist) experiences that which is forbidden in his own 'I,' a yearning for that ocean of feeling, whose waves batter the shore with a resounding clatter, and which begins to sing in every heart that is connected to another in the broad, open, brotherly, shared humanity ?"18 According to Lunacharskii, every form of expression produces an emotional rhythm that resonates not only within the speaker, but also within those who encounter it. The sense of this rhythmic resonance creates the "ocean of feeling" that connects the different members of a social body to one another. The idea that expressed emotion belongs to a particular "I" is for Lunacharskii a bourgeois concept, which dampens and conceals this connection. Socialist poetry, he argues, eviscerates the "I," and reveals that while members of a social body may be distinct, they are not separate. Such poetry also exposes the experience of profound joy (radost') that accompanies the resonant harmony of this "shared humanity," and in so doing unleashes the desire for its repetition. Joyful, empathetic social connections, as by-products of the poetic breakdown of the bourgeois "I," become fundamental components of the socialist collective. 
9 Although Lunacharskii emphasizes the role of joyful, empathetic resonance in the formation of a collective social body, he also argues that it is not the only factor critical to that body's development. Dissonance and struggle are equally critical. In Lunacharskii's theory of aesthetics, the materials of expression that initiate resonance also initiate dissonance. Just as the joy of harmony is experienced and produced collectively, so too is the disruption of dissonance. Dissonance pushes the members of the social body to critically examine and "work over" (razrabotat') the sources of disruption. This "working over," which Lunacharskii also describes as a struggle (bor'ba), drives the creation of innovative forms (novatorstvo). In the process of creation, the drive to work over the source of dissonance couples with the desire for the joy of intimate harmony, and in so doing, ensures that the products of creation are not formed in opposition to what already exists or has been expressed, but as reconciliations. They include new and perhaps dissonant elements, as well as familiar elements known to resonate with the broader collective. According to Lunacharskii, the artist-socialist's second task is to expose the dissonant elements of creation, as they exist within resonance. ${ }^{19}$ Such works facilitate a type of collaborative, "brotherly" communication that not only allows dissonance, but that mobilizes it as a productive and innovative force. In so doing, they contribute to the development of a social body that is not organized by the forms and movements of production, but that is "artistically organized" by the rhythms of the bodies that create those forms and conduct those movements. Lunacharskii argues in his 1923 text Foundations of Positive Aesthetics that while the forms that such a social body creates cannot be imagined in advance, the fact that they emerge from an intimate, brotherly struggle ensures that they will generate joy. For Lunacharskii, the sensual quality of happiness is far more definitive of a socialist collective than its visual appearance. "And what happens," he asks rhetorically, regarding the transformation of a member of the collective, "when what he sees does not result in the erection of a cathedral? He puts himself in the hands of humanity, and delights in that which marginally approximates the wooden frame of a building, and finds his own happiness in the struggle itself, in creation itself." ${ }^{20}$

10 Lunacharskii first began to advocate figurative realist painting as an art for the socialist collective in his 1923 lecture "Art and the Working Class." He delivered the lecture at the History Museum in Moscow, as part of a ceremony honoring Nikolai Kasatkin, a realist painter who had been a member of the pre-revolutionary faction of artists known as the Wanderers. Lunacharskii argued that art would actively engage the proletarian spectator only if its visual content resonated with the spectator's own experience. ${ }^{21} \mathrm{He}$ had asserted in his earlier writings that the working class, as the most collectivist social class, was already familiar with the intense corporeal experience of collaboration, which he also described as the "poetry" of the proletariat. ${ }^{22} \mathrm{He}$ argued that Kasatkin's figurative realist paintings were relevant to the current post-revolutionary moment, because they employed a maximally comprehensive visual language and were in tune with the internal rhythm of the emerging social order. Lunacharskii emphasized that once such pictures were displayed and circulated each one would function as an affective material presence (nalichnost'). As such, each would be capable of igniting collectivist, proletarian feelings. ${ }^{23}$ Although his assessment of realism's potential is positive, Lunacharskii also states that Russian artists have not yet produced a type of figurative realist painting that fully expresses the proletarian experience. This experience, however, has been expressed in poetry. He writes that Dem'ian Bednyi for example, uses "a simple and accessible 
language that everyone understands, which is supported by the people, and which awakens them and calls them to communism. He knows what to say to a worker, to a man, to a Red Army soldier." ${ }^{24}$ Realist painting will reach its full catalytic potential only when artists create a figurative visual language that can do the same.

While Lunacharskii suggests in "Art and the Working Class" that figurative realist painting can have the same catalytic effect as verse, he does not describe how still and silent easel pictures, as a kind of mediating presence, might initiate the development of this "life affirming" continuity. He addressed this issue for the first time in his 1925 review of AKhRR's work "Puti iskusstva [The Paths of Art]." In this text, Lunacharskii discusses the difference between figurative painting's effect on social relations, and collaboration in particular, and the effect of photographic images. His careful consideration of these differences and the subsequent refinement of his argument about the need for figurative painting was prompted by the radical modernists' push for the abandonment of "old, bourgeois" visual media, such as painting and drawing, in favor of film and documentary photography. ${ }^{25}$ Lunacharskii was not opposed to the photographic medium in general. He was, however, concerned that the camera's increased ease of operation would lead to the endless production of haphazard individual shots (snimok). In the premiere issue of the journal Soviet Photo, Lunacharskii described photography as an important technical tool, through which the Soviet public, and especially children, could gain a more comprehensive view of themselves and their world. ${ }^{26}$ One of the medium's greatest strengths, in his view, was its ability to fix the gestures of the body and facial expressions formed within a particular context. ${ }^{27}$ In so doing, a photographic study had the potential to offer the viewer new insight into the physical experience, or "poetry," of the body at a given moment. However, if captured too quickly, with little attention to these corporeal details, the photographic image's material traces, he suggested, become subordinate to the homogenizing effects of the camera's optical technology, and the picture loses its art. ${ }^{28}$

12 Lunacharskii blamed the proliferation of quickly produced photo-stills for what he described as the curious disappearance of painting from the works AKhRR presented at the exhibition Revolution, Everyday Life, and Labor. Whether the tendency to produce "a good photograph colored in a more or less satisfactory manner" in lieu of a painting stemmed from a conscious attempt by the AKhRR artists to mimic the frames produced by portable cameras, or whether it was an unconscious result of the influence of the technology of photography made little difference to Lunacharskii. He points out that while such documentary shots produce images of a single moment in time, they fail to convey the vivid colors and palpable textures of lived experience. ${ }^{29}$ As a result, such photographs do not fix reality; they offer a lackluster, mechanical reflection of it. The fact that the AKhRR artists, who by 1925 had earned a reputation as the most active and vocal defenders of realist painting, were generating only "good photographs" with satisfactory color work suggested to Lunacharskii that the increased reliance on industrial technology was generating not socialist creators, but standardized producers. He argues that the "brightness of the paint" and the artist's "love for the material, for reality" are both critical to the development of socialism. Their absence from the pictures in the AKhRR show indicates the emergence of a mechanical and routinized social body, rather than the intimate, sensual, and collaborative collective that he argued Kasatkin had begun to express in his paintings. If these properties had been present in AKhRR's work, or the work of any other artists, Lunacharskii writes, "we would have arrived at a 
kind of painting, which presents in itself a completeness, crystallization, where the foundational idea, the foundational feeling, the foundational thought dominates everything, we would be able to ignite and convince everyone [to become communist]." ${ }^{30}$

13 Lunacharskii singled out Fëdor Bogorodskii's portraits of orphaned children (see fig. 1, Portrait of a Homeless Boy) as exceptional, because of the textured materiality of their visual surfaces. Although Bogorodskii was a recognizable figure among Moscow's politically engaged artists, he was not known for his figurative realist paintings. The artist had initially aligned himself with the Futurists, and produced colorful, semi-abstract portraits of figures involved in the arts. Revolution, Everyday Life, and Labor was the first exhibition that Bogorodskii participated in as a member of AKhRR, and it marked the beginning of his striking turn from Futurist abstraction to figurative realism. ${ }^{31}$ The artist's handling of paint and his approach to the rendering of the figure do stand out when compared to the work of other realist painters, such as Isaak Brodskii, who also contributed to the exhibition. The surface of Brodskii's Lenin against the Background of the Kremlin (fig. 2, 1924) is so smooth and polished that it shines. This effect endows all the canvas's pictorial elements, including the greenery of its garden landscape, the sprawling corpus of the Kremlin, and the figure of the Bolshevik leader himself, with an ethereal glow. Brodskii also combines light and dark oils in a way that implies substance without adding texture. The result is most visible on Lenin's face, where the lines and ridges formed from thought and age take shape and appear to press against the canvas's smooth, shiny surface, which ultimately denies them a tactile presence.

Fig. 2 - Isaak Brodskii, “Lenin against the Background of the Kremlin," 1924

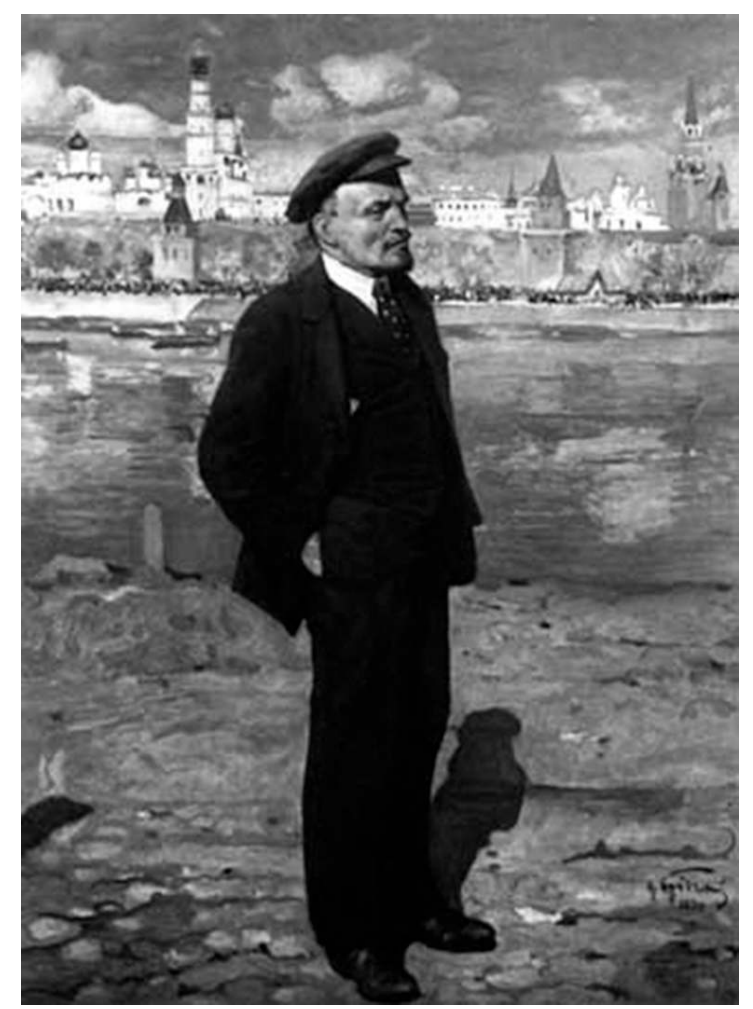

OIL ON CANVAS

LENIN MUSEUM, MOSCOW 
In contrast to Brodskii's figure of Lenin, the street urchin in Bogorodskii's Homeless Boy has not been constructed from techniques that create the illusion of material substance, but from a combination of distinct, palpable textures. The vertical and diagonal lines that the artist has made from thick applications of dark brown paint come together to form the boy's ill-fitting overcoat. They also endow the coat's recognizable shape with a rough-hewn texture that both shows the wear and tear on the cloth and gives the viewer a tactile sense of the effects of material hardship. Although this palpable surface fills the lower half of the picture's frame, Bogorodskii casts it in shadow in order to emphasize his subject's face, which is the only aspect of the picture that is illuminated. The soft glow around the figure's head highlights the mottled tones of his flesh, and also reveals that his most prominent features -his high cheekbones, his broad, misshapen nose, his heavily lidded eyes, and his pursed lips - have been built up from layers of contrasting hues of paint. These features do not appear flush with the surface of the canvas. Instead, they press outward, giving the painting a raised, slightly sculptural quality. The differences between Brodskii and Bogorodskii's finished canvases may be explained, at least in part, by their particular approaches to the process of painting. Brodskii allowed himself to work from photographs, while Bogorodskii asked the subjects of the Urchins series to pose for him in his studio. ${ }^{32}$ Indeed, the question of whether or not a socialist painter should work from a photograph of his subject remained a point of serious contention within AKhRR until the organization's dissolution in 1932.

Lunacharskii argued that unlike the other AKhRR artists, Bogorodskii's particular handling of the materials of painting allowed him to convey his figures' corporeal presence. Rather than reflecting his subject's image, as his comrades' work had done, this substance, as Lunacharskii explains in his praise of Bogorodskii, revealed their affect :

He gives us the exterior, the appearance. He gives us pure matter, as it relates to "behavior," which our new scientific psychology is just beginning to study. We must know the person... We must strive to attain an exact knowledge of the experience of the person from his external manifestations. Human feeling, frame of mind, is very immediate and can be difficult to consider, but the way in which it is reflected physiologically, in the pose, through the very entirety of the construction of the figure, has a great indicative meaning. ${ }^{33}$

In Lunacharskii's view, the unique potential of Bogorodskii's canvases to "artistically organize" the collective stemmed from this ability to impart "an exact knowledge of the experience of the person from his external manifestations." Since, according to him, "human feeling," as the "poetry" of "experience," is the source of innovation and collaboration, only pictures that manage to convey emotion, as it reverberates within the material substance of the body, in its "blood and nerves," can contribute to the development of a self-sustaining, socialist collective. Lunacharskii emphasizes that Bogorodskii expresses the sense of emotion "physiologically, in the pose, through the very entirety of the construction of the figure." His particular arrangement of the color tones that form the figure's face and his emphasis on the material qualities of the painterly medium result in a picture that appeals to the sense of touch. The Austrian art historian Alois Riegl introduced the term "haptic" in the late nineteenth century to describe works that simultaneously address the visual and the tactile. ${ }^{34}$ In his work on the contemporary British painter Francis Bacon, Gilles Deleuze provides a more nuanced definition of the term, arguing that hapticity in painting emerges when the artist subordinates the figure neither to the optical, nor to the manual techniques of visual representation, but "when sight discovers in itself a specific function of touch that is 
uniquely its own, distinct from its optical function." Although the term "haptic" is not included in Lunacharskii's text, his own description of Bogorodskii's paintings as images that use the techniques of painterly construction to convey the corporeal "experience" of emotion anticipates both Deleuze's definition of haptic painting and the French philosopher's subsequent discussion of its political function. This is not surprising given that both Lunacharskii and Deleuze drew upon Spinoza's philosophy of affect as they developed their individual arguments about sensation and political subjectivity. ${ }^{35}$

According to Lunacharskii, Bogorodskii's ability to sense and convey this hapticity indicates a deep connection to the proletarian collective. Even though the subjects' youth and hardscrabble existence at first alienated Bogorodskii, the artist's receptiveness to their corporeal "reality" (deistvitel'nost') allowed him not only to see the effects of such an existence, but also to physically sense them. Lunacharskii argues, however, that the resultant revolutionary portraits, which appear to have been created in the artist's "blood and nerves," convey neither Bogorodskii's own experience nor that of the subjects he draws. The artist's "blood and nerves," in Lunacharskii's view, are the sites of resonance and dissonance, which at once unite and disturb the social body. By conveying affect through the techniques of haptic painting, Bogorodskii reveals these shared resonant and dissonant components. His pictures, once circulated as affective presences, will have the potential to contribute to the development and sustenance of a socialist collective. $^{36}$

In "Puti iskusstva," the aspects of Bogorodskii's figures that convey disruption are emphasized over all of the other aspects of the pictures. In his earlier texts on aesthetics, Lunacharskii described the struggle with the dissonant elements inherent to expression as a productive, and even joyful, collective experience. Here, however, he argues that the artist's haptic portraits reveal that the extremes of recent history -world and civil war, material depravation, infectious disease epidemics, etc. - have created a social body that is not just riddled with dissonant elements, but marred by painful scars. Lunacharskii argues that Bogorodskii's presentation of the most visceral aspects of the existence of the children "who grow up among the wolves," allows the spectator to feel, and thus be reminded of the devastating collective consequences of the events of recent history. ${ }^{37}$ The development of this empathetic sense memory, he argues, is a necessary component of the materialist social analysis that will lead to communism.

19 Lunacharskii's critique of the influence of photographic technology and his praise of Bogorodskii's work brought a series of critical questions to the fore of the early Soviet art debates: Was photography altering vision and visual production so as to obscure the aspects of creation that are sensed in the "blood and nerves?" What were the possible implications of this effect on social relations? Could Bogorodskii or AKhRR's realism convey corporeal sensation in a way that would aid the development of connections that could be described as socialist, or were their serious drawbacks to such a method, which relied on pre-revolutionary forms of figuration? Osip Brik and Boris Arvatov, two theorists associated with Lef and Constructivism, responded publicly with arguments in defense of photography that both acknowledged and disputed Lunacharskii's claims. While they conceded Lunacharskii's point about the importance of color and surface texture in the development of collectivist social relations, they also argued that figurative painting's potential as a means of socialist representation was limited by the easel's static form. They accused AKhRR of redrawing, rather than breaking down, socially constructed boundaries between the members of the collective, and in so doing of contributing to the 
formation of a social body comprised of individuals with the capacity for expression, which would resemble the pre-revolutionary public body more than a socialist collective.

\section{Photography and the Visualization of Socialist Circuits : Lef's Response to Lunacharskii}

In the summer of 1925, Nikolai Chuzhak, a Proletkul't theorist and writer for the journal Lef, published a response to Lunacharskii in the journal Sovetskoe iskusstvo [Soviet Art]. Whereas Bogdanov imagined that industrial methods of representation would equalize the social body through psychological homogeneity, Chuzhak argued that the interaction with the means of mechanical reproduction, such as photography and film, would eradicate the form of the individual body altogether. ${ }^{38}$ In an industrial collective, the proletarian would not work with the new dynamic means of production; he would be integrated into them, as a critical component of the system, which Chuzhak refers to as "the plan."

Chuzhak argued that easel painting's static, mounted surface, in contrast, encourages the viewer to become trapped in an "illusionistic" state, in which he/she passively considers his/her own idea of reality instead of working with its material substances. He uses the example of theatre to clarify his argument :

Theatre's traditional two-dimensionality (decoration) obviously surrenders to the onslaught of the "thing-model." The traditional box-like quality (the elevated stage) is invaded and almost frighteningly seized by film and the circus. Tomorrow, I fear that the noise of the phonograph and the radio will burst forth from the street. The traditional distinction between "artist" and "spectator" will be shamefully driven from common use. ${ }^{39}$

The stage set example is at once literal and metaphorical. From Chuzhak's perspective, the superficial relationship that an actor develops between himself and his set decoration illustrates the experience of everyday life before the October Revolution. Although the spectator saw the material components of the world in which he/she lived, he/she did not physically apprehend them or work them over. His/her relationship to the material world was grounded in the idea rather than the experience of matter, and the role he/she play-acted in the world was defined by his/her relationship to the idealistic images of the things that surrounded him/her. Chuzhak contends that once objects, such as easel paintings, which maintain this idealistic experience, are replaced with dynamic, standardized means of production, the disconnected bourgeois actor-subject will disappear forever. The new social body will be formed from a continuum of "thing-models" (veshchi-modeli) that are connected to one another through the means of their production. According to Chuzhak, each mechanically generated thing-model combines utility (in the thing itself) with innovative potential (in the model). Although thing-models emerge ready for use, their model aspect also renders them open and incomplete. It is this innovative openness that catalyzes the next cycle of creative production..$^{40}$ There will be no unique "artists" or passive "spectators," because all the constituents of the social body will be embedded in the processes of production-creation.

Chuzhak emphasizes that although the constituents of the "thingly" (veshchnoe) continuum will be inseparable from the substances of production, their capacity for creativity and innovation, as expressed in the model, ensures that they will be conscious agents. ${ }^{41} \mathrm{He}$ writes that the "thingly beginnings of a life-organizing art" issue from the 
thing-model's "active-engineering approach to the building of the epoch." "It is impossible," Chuzhak further explains, "to organize the willful-consciousness (volesoznanie) of the environs (sredy) without things." ${ }^{42}$ Chuzhak's conflation of "willful-consciousness" with the material environs suggests that even in an "unorganized" social system, willful agents cannot really be separated from any of the objects, and their associated ideologies, with which they interact. However, in an "organized" social body, collective, willful-consciousness will be directed toward the maintenance of the system, or "plan," whose purpose is implicated in the industrial means and processes themselves. ${ }^{43}$

After Chuzhak articulated his theory of the thing-model, his Lef colleague Osip Brik published an essay about the role of the photographic medium in the organization of the collective. "The Photo-Still against the Picture" appeared in the second issue of Sovetskoe foto. Brik criticized AKhRR's promotion of easel painting, and argued that neither their work, nor any other type of painting was capable of the "transmission of reality" (peredacha deistvitel'nosti). ${ }^{44}$ Photographers, he explains, have too often tried to mimic such painting. ${ }^{45}$ Now they must change their approach :

A photographer must create things, photo-stills, from the foundational principle of his craft, from the principle of the exact fixation of nature, whose strength of effect on the spectator, as a matter of course, will not be surpassed by any artist's paintings. The photographer must show that the impression he makes is not one of a life ordered according to aesthetic laws, but of the vivid reality of life itself, which is fixed in a technically perfect photograph. ${ }^{46}$

A photographic frame, in Brik's view, is capable of "fixing," or transmitting a visual impression of the "vivid reality of life itself," because of its direct link to the means of the new industrialized existence. As such, it has the potential to allow the viewer to see how new media technology forges connections between entities that have appeared distinct and even isolated. Brik also refers to photo-stills as "things" (veshchi). His argument that the "social significance" (sotsial'naia znachimost') of photo-stills is rooted in their ability to fix and transmit "nature" (natura), suggests that he thinks of these objects as visual thing-models. ${ }^{47}$ They are not just products of the industrial means of creation. Their mechanically generated form reveals both the inherent connectedness of things and the inevitability of their creative transformation.

Three photographic images are reproduced alongside Brik's text. They include two of Aleksandr Rodchenko's "stills" of Moscow's urban landscape (see fig. 3, The Yard of House No. 17 on Miasnitskaia Street, c. 1925), and a single documentary shot of an "urchin" (besprizornyi) (fig. 4, c. 1926) by the Moscow photo-reporter N. Skriabin. Brik praises Rodchenko for having "consciously moved away from painting," and explains that although the photographer's work is still in a "laboratory" phase, he is beginning to formulate an approach that reveals the ways in which new media technologies are altering everyday life. ${ }^{48}$ Brik makes no reference to Skriabin's photograph. Indeed, it is possible that Sovetskoe foto's layout designers did not consciously consider the relevance of Skriabin's picture to the photography debate when they inserted it next to Brik's text. The image, which bears the singular form of the same title as Bogorodskii's Besprizornye series, nonetheless offers a provocative contrast to Lunacharskii's argument about the significance of Bogorodskii's Homeless Boy. Photography's basis in time allowed Skriabin to record his own bedraggled subject with his mouth agape, reacting to an occurrence just outside the frame. By capturing him in the act of response, Skriabin not only reveals the youth's involvement in everyday life, he also makes him a component of it. As a 
photographic presence in the emergent Soviet media, the boy is no longer a lone, struggling individual. He becomes an open visual artifact of a particular moment, to be integrated, upon apprehension, into the broader loop of dynamic socialist things and collectivist re-creation. The photograph's monochrome does, however, deprive the image of the youth of the tones and textures that remain part of even the fastest, most technologically advanced aspects of reality. Despite their enthusiasm for the photographic medium, both Brik and his Lef colleague Boris Arvatov acknowledged that these absences limited photography's potential as an instigator of social change.

Fig. 3 - Aleksandr Rodchenko, "The Yard of House No. 17 on Miasnitskaia Street," c. 1925.

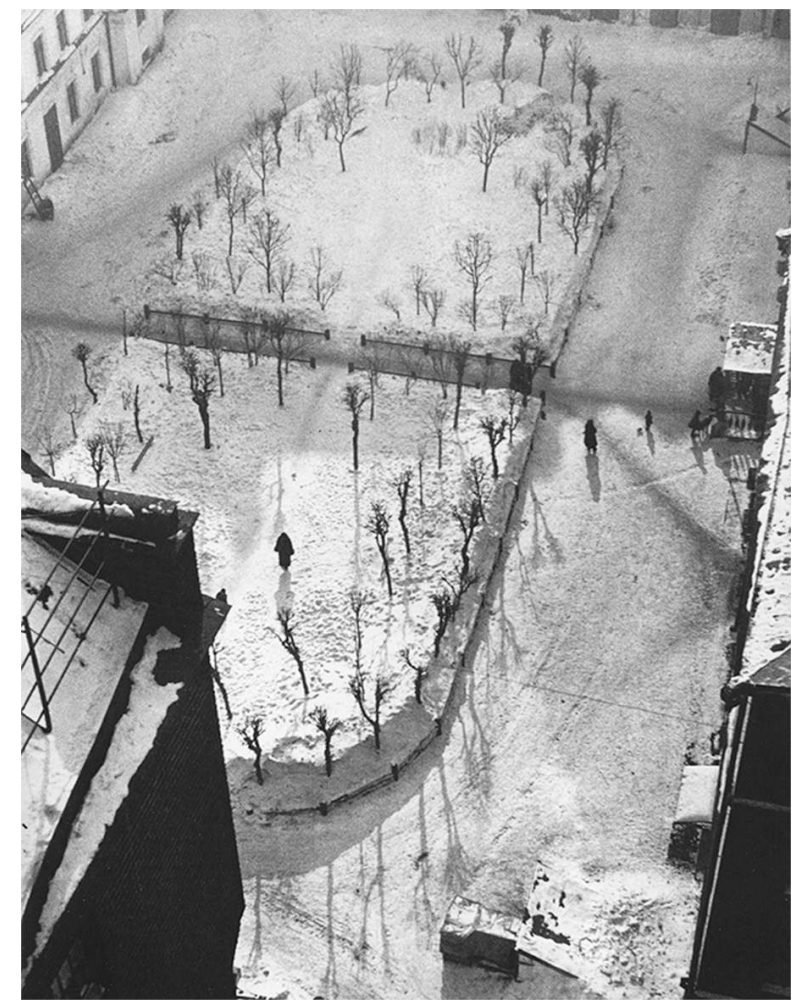

Reprinted in Soviet Photo, 1926, No 2, as an illustration for Brik's "The Photo-image versus Painting" GETTY RESEARCH INSTITUTE, LOS ANgELES (85-s1021) 
Fig. 4 - N. Skriabin, “Urchin," c. 1926. From the exhibit "Fotoreportazh”.

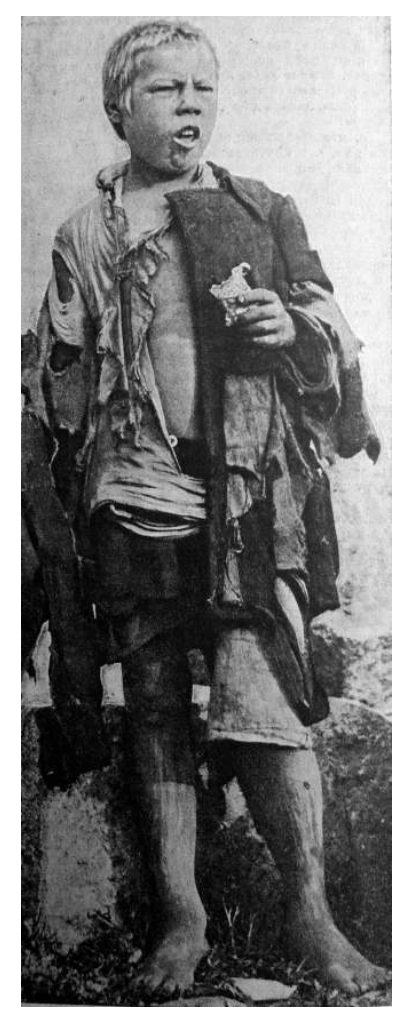

Reprinted in Soviet Photo, 1926, No 2, as an illustration for Brik's "The Photo-image versus Painting"

GETTY RESEARCH INSTITUTE, LOS ANgELES (85-S1021)

According to Brik, until the technologies of production could make images in color, photography would not be able to fully reflect the richness and the vividness of material reality ${ }^{49}$ In the first issue of Lef's reincarnation, Novyi Lef, his colleague Arvatov linked the photograph's lack of color and textural distinction to the persistence of the Soviet public's demand for easel painting. "Reality is a light-colored (sveto-tsevtnoe) and 'factured' (fakturnoe) (possesses qualitatively distinct surface properties) phenomenon," Arvatov writes, "and as long as photo and film have not attained light-coloring or facturizing technologies, painting, as the cognitively-active art, will remain the monopolist of 'reflection'." 50

Arvatov's description of painting as the "cognitively-active art" can be read as an acknowledgement of Lunacharskii's point about the significance of tactility and corporeal sensation in the development of collective social relations. ${ }^{51}$ Whereas Lunacharskii describes tactility as a poetic instigator of intimacy and productive struggle between distinct bodies, Arvatov suggests that it activates the capacity for a deeper apprehension of materiality in general, and of its sensual aspects in particular. Like Chuzhak and Brik, he took the position that the processes of industrial production, rather than "poetic" interpersonal interaction, would be the driving force of collectivization..$^{52}$ As an activator of cognition, surface texture allows the worker-engineer to gain the broadest possible comprehension of the materials and processes at his/her disposal. Only when he/she attains such an understanding, will he/she be able to create innovative products that maintain and expand the connections between him/her and the other worker-engineers touched by the system. 
29 Arvatov shared his Lef colleagues' view of easel painting as an illusionistic representation of reality, which distracts the viewer from the materials and means of modern production. ${ }^{53} \mathrm{He}$ also offered an expanded and more nuanced argument about the effect of the easel's colored and "factured" surface on the viewing subject. Arvatov compared its function to that of a commodity object..$^{54} \mathrm{He}$ asserted that the experience of cognitive activation that the viewer gains from looking at a mounted painting encompasses pleasure. ${ }^{55}$ However, like a commodity, an easel painting, as an object confined to a frame and placed on display, keeps him/her distracted from the aspects of modern life that challenge the validity of such an existence by infusing the experience of isolated apprehension with sensual pleasure. Arvatov asserts that as long as film and photography lack a "colored-factured fixation of reality, the everyday life of the private-economy will remain in place; everyday life has not yet attained socialism through the art of the working class." ${ }^{56}$ Once film and photography do develop the technological means necessary to "fix" and "transmit" the colored and "factured" surfaces of the collectivizing forms of industrial production, the viewer will not only come to understand how they work, as Brik suggested, he/she will know that contact with them will bring him/her great pleasure. When this happens, he/she will come to desire the dynamic objects of industry, and this desire will result in the formation and expansion of the collective. Arvatov contends that where there remains a space and a demand for easel painting, the collective social body does not, and indeed cannot exist. ${ }^{57}$

Aleksandr Rodchenko changed his approach to the photographic study of the objects and spaces after the publication of Brik and Arvatov's essays. Apart from his disorientating "bird's eye" and "worm's eye" views of figures and spaces, he also began to produce extreme close-ups of the component parts of industrial production, which were published alongside journalistic accounts of factory life in mass media periodicals such as 30 dnei [30 Days] and Daësh! [Let's Produce !]. ${ }^{58}$ The photograph Stereotipy [Printing Plates] (fig. 5, 1928), which appeared in 30 dnei, is a representative example of this type of work. In it, Rodchenko presents six newspaper typographic plates, which stand erect and aligned one behind the other. By focusing his lens at such close range, he reveals the details of the plates' "factured" surfaces. Although the image is still monochromatic, Rodchenko has developed a technique that allows him to show how the light reflects off the plates' convex forms at the exact moment of photographic capture. This reflection infuses the textured surfaces of the plates with a soft, lustrous glow, which suggests that their utility is the source of their sensual appeal..$^{59}$ As Christina Kiaer has shown, the Constructivist objects that Rodchenko created in the mid-1920s can be understood as transitional things. Like commodity objects, these NEP-era Constructivist objects appealed to corporeal desire in order to engage the consumer, but their innovative design worked to encourage intimate forms of socialist consumption, rather than fetishism and alienation. ${ }^{60}$ Within the context of Rodchenko's oeuvre, his close-ups of the things of production can be thought of as the next phase of his effort to develop "comrade objects" that could promote not just socialist consumption, but also socialist production. By emphasizing tactile luster as a quality of the components of industrial labor, Rodchenko's photograph of typographic plates works to redirect the viewer's desire toward a process that he imagined, through its particular sensual appeal, would encourage broad social connectivity and transparency, rather than alienation and concealment. 
Fig. 5 - Aleksandr Rodchenko, “Printing Plates."

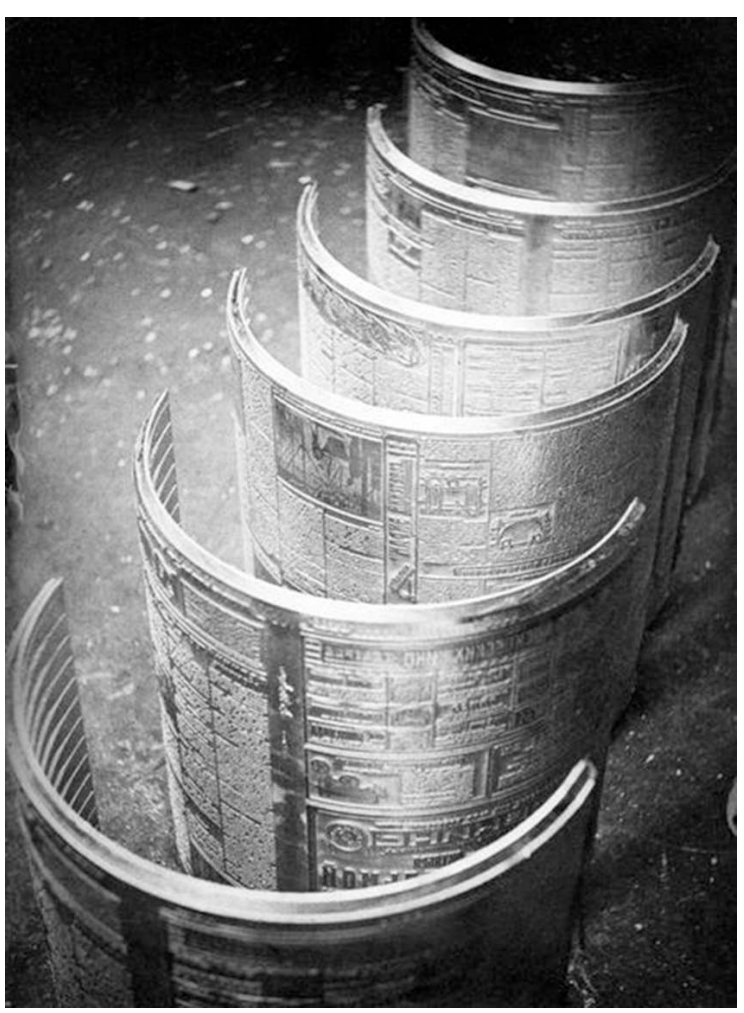

ILLUSTRATION FOR THE ARTICLE "OCHERK ABOUt A NEWSPAPER" FOR THE MAgAZINE 30 DAYS, 1928

The photo-works that Rodchenko produced between 1928 and 1929 became integral components of the practice of documentary "factography." ${ }^{61}$ These techniques were designed not only to convey information to the Soviet masses, but also, as Devin Fore has shown, to establish "the parameters of a language commensurate with advanced industrial existence." 62 The Soviet public's continued demand for forms of "mounted art" (stankovism), such as easel painting, prompted the "factographers" to accelerate the development of their theory of a language that could not only convey, but embody industrial experience. It also prompted them to advocate its drastic implementation.

As Fore demonstrates, the dramaturge and Lef theorist Sergei Tret'iakov drew upon Aleksei Gastev's empirical studies of the psycho-physiology of labor as he worked to develop ideas for types of journalistic writing that could combine mechanically generated forms of speech with the qualities of materiality that function as "cognitive-activators" by igniting corporeal sensation. ${ }^{63}$ These "operative" words would not only re-make the author, or "operator," by integrating him/her into the collectivizing means of production during the process of articulation, but as sensate activators, they would also precipitate innovative contributions to further development of the plan. ${ }^{64}$ From Novyi Lef's perspective, genuine socialist communication would not emerge until this industrial language permeated all aspects of representation. The photo-still would also be central to this process of reformation. Its newly "factured" surface would not only reveal the sensual allure of the industrial means, but as an industrial thing-model, the still would alter the viewer's approach to the apprehension of the visible world. 


\section{The Cultural Revolution and the Invention of Socialist Visual Media after Lef and Lunacharskii}

33 1928 marked the beginning of a new period of cultural upheaval in the USSR. The unveiling of the first five-year plan coincided with a demand, especially from Soviet youth, for the establishment of a proletarian dictatorship. ${ }^{65}$ At this time, a group of Marxist art historians affiliated with the Communist Academy declared their dissatisfaction with both AKhRR's painting and Novyi Lef's media theory. ${ }^{66}$ This new "October" group (Vserossiiskoe ob"edinenie pabotnikov novykh vidov khudozhestvennogo truda "Oktiabr") described its primary task as the creation of forms of visual art that could help the proletariat build a "socialist economy and culture" founded on the highest levels of "organization, planning, and industrial technology" according to its own demands. ${ }^{67}$ Although October's theorists criticized Novyi Lef in the press, the group's emphasis on the importance of "organization, planning, and industrial technology" betrays a shared interest in the ideas about the formation of a collectivized proletarian culture from the standardized means of industrial technology. ${ }^{68}$ Indeed, the October writer Aleksei Mikhailov, in his 1928 article "Film and Painting," affirmed Lef's position that mounted easel painting creates a barrier between the proletarian subject and the material world. ${ }^{69}$ Mikhailov further argued, echoing Chuzhak, that because film and photography could be projected and disseminated, they would soon alter the experience of spectatorship so that the viewer would see and sense his/her connection to both the broader masses and the materials created within the socialist collective. ${ }^{70}$

Although the position of the October group about the role of filmic and photographic media in the formation of the collective was similar to that of the Novyi Lef writers, Al 'fred Kurella, a key October theorist, was quick to articulate a critical difference. "But the principle of a planned, organized, and strict-scientific approach by the artist to his work," Kurella writes, "cannot be promoted as an end in itself. Herein lies LEF's mistake." According to Kurella, the proletarian's conscious mind and his capacity for agency distinguish him from the mechanical materials he works over. In Kurella's view, if the distinction between human consciousness and mechanical process is erased, if "willful-consciousness" becomes fused with the industrial means as Chuzhak suggested it should, the proletarian risks subordinating every aspect of himself, including his capacity for critical innovation, to the plan of those means. ${ }^{72}$ Kurella emphasized that while the forms of industrial production would play a significant role in "organization" of the collective, art had to be maintained as a semi-autonomous element within these means. ${ }^{73}$ "Art," Kurella explains, "belongs in the realm of the ideological order of social phenomena." 74 That is, it expresses ideas and catalyzes further generation without risking the subordination of the body to the plan of the means. From Kurella's perspective, art is a source of both conscious and unconscious thought. As such, it functions as the element of form that maintains the worker's capacity to critically consider and rework all aspects of the materials of production from a proletarian perspective, including the plan itself. ${ }^{75}$

Following Kurella's criticism, the October group declared its primary task to be the determination of the place of "all forms of art on the front of the socialist revolution."76 The adoption of this position led to a reconsideration of the role of aesthetics in mechanical reproduction, and fostered new approaches, from among the group's artist 
members, to the media they considered collectivizing. The October group emphasized film and photography and objected to the static form of the easel, but unlike their colleagues at Novyi Lef, they did not advocate the abandonment of the materials of painting altogether. They included the more general word for the medium -zhipovis'in the list of forms of art that they consider appropriate for a proletarian society, as if to encourage not only the members of their group, but also other contemporary artists to continue to experiment with painting's aesthetic possibilities. ${ }^{77}$

October's formation precipitated a rift among the members of AKhRR over the status of painting. As a whole, the group embraced the principles of the Cultural Revolution, including the push to expand the activities the Bolshevik Party's cultural institutions into the Soviet Republics outside Russia. In 1928, the group members' changed their collective name from the Association of Artists of Revolutionary Russia (AKhRR) to the Association of Artists of the Revolution (AKhR), in order to reflect their support for these cultural initiatives. ${ }^{78}$ The group's younger members argued that in order to expose the ways in which the industrial means of production were connecting members of the proletariat and to eradicate all forms of individualistic, bourgeois spectatorship, they needed to place more emphasis on public art and mechanical reproduction..$^{79}$ The older members, on the other hand, continued to argue for the relevance of figurative easel painting. In 1930, the two sides reached a compromise. Easel painting, as a form of "bourgeois" art, was de-emphasized, though not totally abandoned, in favor of print media, including AKhR's journal Art to the Masses, frescoes, posters and postcard reproductions of the group members' paintings, of which Evgenii Kastman's 1925 They Are Listening (fig. 6, postcard reproduction, 1930) is one example. Despite their concession to October's position, AKhR's decision to reprint their figurative paintings suggests that while the new mechanical media were becoming the primary means of apprehending the world, as Lef had hoped, mechanically reproduced forms could not alone activate the corporeal awareness necessary for the development of intimate, comradely connections and social analysis. ${ }^{80}$ The turn away from the painted surface toward its reproduction also indicates that the haptic contours of pictures such as Bogorodskii's Homeless Boy are no longer accepted as the only visual techniques that could ignite corporeal recall. AKhR's shift suggests that the memory of the organic materiality of painting, which its reproduction conjures, was also considered to have the potential to activate the sensations that remind a body of the qualities that differentiate it from the machine apparatus. ${ }^{81}$ 
Fig. 6 - Evgenii Katsman, “They are Listening.”, 1930

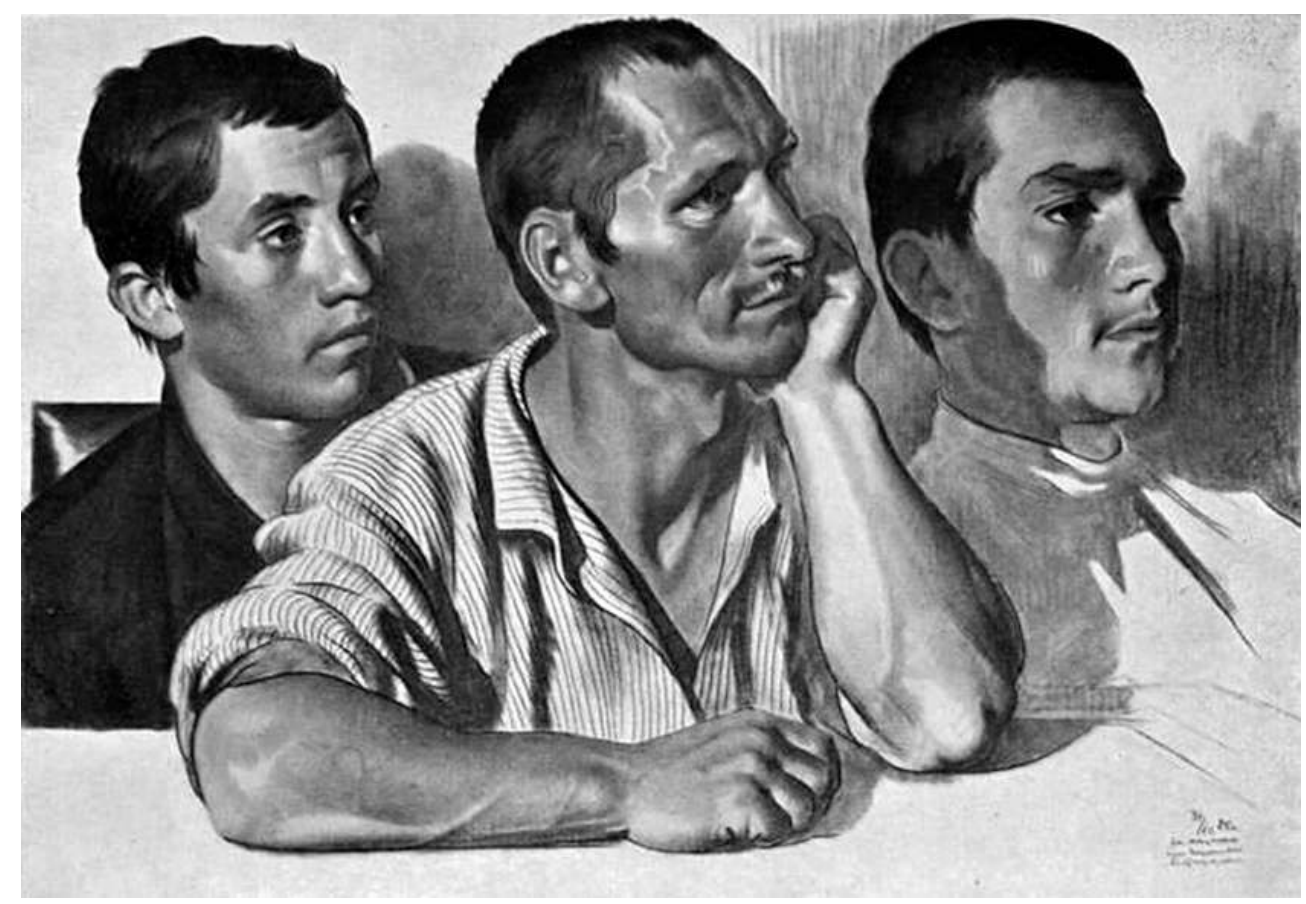

PICTURE POSTCARD PRINTED FROM 1925 gRAPHIC WORK WITH THE SAME TITLE.

COLLECTION OF THE STATE CENTRAL MUSEUM OF THE CONTEMPORARY RUSSIAN HISTORY, MOSCOW

Although the antagonistic debate between AKhR and the October group about the definition of art and the role of the medium in the formation of proletarian consciousness continued throughout the period of the Cultural Revolution, the opposing groups agreed on two specific points. They agreed that the forms of mechanical reproduction were crucial to socialist art, because of their perceived ability to reveal and forge connections between socialist subjects. They also agreed that the medium of painting would play an important role in the development of socialism through its particular appeal to the living body, which they perceived as the site of proletarian consciousness. The format of the postcard allowed both the sender and the recipient to see the image of painting, ensuring that both the composition and the reading of text were informed by whatever corporeal reaction the content of the picture precipitated. AKhR's campaign for postcards met little resistance from the October group. By the end of 1932, these objects, which combined the traces of painterly materiality with the forms of mechanical production, had become integrated, like the photo-still, into the stream of visible socialist things. ${ }^{82}$

Figurative paintings and their postcard reproductions remained central to Soviet visual culture throughout the USSR's turbulent history. ${ }^{83}$ The arguments that Lunacharskii and Arvatov, two prominent theorists who usually disagreed over questions of socialist culture, advanced about the relationship between the materiality of painting and corporeal sensation and the critical role of that relationship in the fostering of socialist connections suggests from the very inception of Soviet visual culture such paintings were considered not lifeless objects to be admired from a distance, but active, mediating forces within the social body. That the members of AKhR and the October group later agreed that painting's particular appeal to the corporeal functioned as an activator of proletarian consciousness further suggests that by early 1930s, in the cultural sphere at 
least, the new Soviet human was conceived of as an entity, whose capacities for perception and thought were rooted in the substance of his/her flesh. The immediate acceptance and subsequent proliferation of postcard reproductions of Soviet figurative paintings suggests that these objects were conceived of not just as pictures, but also as visual objects synonymous with the flesh of the body. The aim of this essay, in elucidating the connection between painting and the body, the body and consciousness, has been to offer a framework for a broader understanding of the critical role that painting and its reproductions played in Soviet visual culture and communication theory, and to ask us to consider what role its historical status as mediator of sensation played in the conception and socio-cultural function of displays of original art objects in museums and traveling exhibitions, as well as how it altered the meaning and evolution of Soviet photography.

\section{NOTES}

1. The research and development of the ideas presented in this article could not have been completed without support from both the International Center for the History and Sociology of World War II and Its Consequences at the National Research University-Higher School of Economics in Moscow and the Institute for Advanced Study at the Central European University in Budapest.

2. Lunacharskii's critique of the influence of photography should not be misinterpreted as a call for the total abandonment of the medium. While he remained firm and consistent in his position that painting, as a form of art, was necessary for the development of socialism, Lunacharskii also admitted that photography had unprecedented value as a scientific tool. In the first issue of Soviet Photo he promoted these virtues. "Photography has become the basis of education," Lunacharskii wrote, "and is needed everywhere. No office or laboratory can play as broad a role in the study of things as photography can. On the other hand, photography illustrates every aspect of life, all the aspects of knowledge, which a child receives." A few months later, however, during a debate about AKhRR's work in the Zhizn' iskusstva [Life of Art], Lunacharskii expressed his doubts about contemporary implementations of photographic techniques. He informed his opponents, who included the Lef writers Boris Arvatov and Nikolai Chuzhak, that while still photography and the "kino-eye" (kino-glaz) had the potential to play an important role in the "people's self-understanding" (samopoznanie narodov), the producers of these images had not yet managed to use the media to reveal the aesthetic properties, or "poetry," of their content in the way certain painters had done. See Anatolii Lunacharskii, "Nasha kul'tura i fotographiia [Our Culture and Photography]," Sovetskoe foto, 1 (1926) : 2 ; "Diskussiia ob AkhRR'e [A Discussion about AKhRR]," Zhizn' iskusstva, 33 (11 August 1926) : 3.

3. Lunacharskii, "Puti iskusstva [Paths of Art]," Revoliutsiia, byt i trud [Revolution, Everyday Life, and Labor] (M. : Izdatel'stvo AKhRR, 1925), 16.

4. In his memoirs, Bogorodskii attributes his desire to paint pictures of Moscow's homeless youth to the fact that they were a very visible aspect of Russian urban life in the years following the Civil War. "In the twenties," he explains, "Moscow's streets were full of ragged, malnourished kids, who had lost their own parents or had run away from them in search of food... The train stations especially were filled with these kids." See Fedor Bogorodskii, "Kak ia pisal Besprizornikov [How I Painted Urchins]," in Fëdor Bogorodskii: Vospominaniia, stati, 
vystupleniia, pis'ma [Fëdor Bogorodskii : Memoirs, Articles, Presentations, and Letters] (L.: Khudozhnik SSSR, 1987), 108.

5. The 1962 anthology, Bor'ba za realism [The Struggle for Realism], which is comprised of excerpts from the early Soviet press, offers an overview of the arts' debates. See Viktor Perel 'man, ed. Bor'ba za realizm v izobrazitel'nom iskusstve 20-kh (dvadtsatikh) godov [The Struggle for Realism in the Fine Arts in the 1920s] (M.: Sovetskii khudozhnik, 1962). Lunacharskii's understanding of the realism as a political aesthetic developed in part from his reading of the work of an earlier generation of Russian writers, who had focused on the topic: Chernyshevskii, Dobroliubov, and Pisarev. Lunacharskii delivered a series of lectures on literature, including the "literature of the 1860s," at the Communist University named for Sverdlov, in Moscow from 1924 to 1926. In these talks, he described Pisarev's "Realists" essays, and referred to him as an author, who demonstrated an understanding of the meaning of art. See Lunacharskii, Russkaia literatura: Izbrannye stat'i [Russian Literature: Selected Articles] (M.: Izdatel'stvo Khudozhestvennoi literatury, 1947), 82-83.

6. For a detailed account of the history of OST within the context of the Soviet cultural institutions see Cécile Pichon-Bonin, Peinture et politique in URSS : L'itinénaire des membres de la Société des artistes de chevalet (1917-1941) (P. : Les presses du réel, 2013).

7. In the literature, AKhRR's rise to prominence has until now been attributed either to the group members ideological alliance with the Communist party or to the fact that documentary photography threatened to capture and reveal the less than favorable aspects of modern Soviet life. Boris Groys, for example, in The Total Art of Stalinism, describes AKhRR's work as "an awkward combination of traditional autonomous figurative art and subordination to the crude utilitarian aims of propagating and illustrating the latest party proclamations." Leah Dickerman, on the other hand, has suggested that AKhRR's work and realist painting in general won support, because painting, which lacks the ability to record spontaneously the aspects of Soviet experience that challenged the state's ideological definition of socialism, could help cover up these aspects of life. Socialist Realism, in Dickerman's view, became the Soviet state apparatus's preferred method of representation, because it did not threaten to reveal information that could challenge the dominance of the apparatus itself. See Boris Groys, The Total Art of Stalinism : Avant-Garde, Aesthetic Dictatorship and Beyond (London : Verso, 2011), 29-30; Leah Dickerman, "Camera Obscura : Socialist Realism in the Shadow of Photography," October, 93 (Summer 2000) : 147-148.

8. Among the critics, the art historian Nikolai Shchëkotov was one of AKhRR's biggest supporters. In 1926, he published a detailed text AKhRR : A New Russia in Art, which argued for the political relevance of the group's realist paintings. That same year, Pavel Novitskii, a left critic associated with the avant-garde, also described the relevance of AKhRR's realism in "Regarding AKhRR : A Big Question." Novitskii's conclusion, however, about the work and aims of the group is not like Shchëkotov's, wholly laudatory. See Shchëkotov, AKhRR : Novaia Rossiia v iskusstve [AKhRR : A New Russia in Art] (M : Izdatel'stvo AKhRR, 1926) ; Novitskii, “Ob AKhRR-bolshoi vopros : VIII vystavka AKhRR-'Zhizn' i byt narodov SSSR' [Regarding AKhRR-A Big Question: The VIII AKhRR Exhibition 'The Life and Everyday Life of the Peoples of the USSR']”, Sovetskoe iskusstvo, $6(1926)$ : 33-42.

9. In his recent study of realism in modern literature, Fredric Jameson demonstrates that the historical and theoretical complexities of figuration can be better understood if they are viewed as a consequence of modernity's crisis of language, which resulted in a new understanding of expression. Expression, he argues, as a consequence of embodied "lived" experience, and led to the development of different forms of affective representation, which often relied on the image of the figure. Devin Fore, in his intellectual history of European interwar realism, has also shown that for certain artists, such as László Moholy-Nagy, the re-integration of the figure was the result of an attempt to understand how mechanical reproduction and new optical technologies 
had altered not only somatic experience, but the very understanding of subjectivity. This essay begins to describe Soviet interwar realism's place within this new scholarship on the modern phenomenon of affective figuration. See Fredric Jameson, Anti-nomies of Realism (London: Verso, 2013), 32 ; Devin Fore, Realism after Modernism: The Rehumanization of Art and Literature (Cambridge, MA : MIT Press, 2012), 25, 52-53.

10. For more on the history of Lunacharskii and Bogdanov's relationship see Sheila Fitzpatrick, The Commissariat of Enlightenment: The Soviet Organization of Education and the Arts under Lunacharsky, October 1917-1921 (Cambridge : Cambridge University Press, 1970), 2-7.

11. Aleksandr Bogdanov, "Puti proletarskogo tvorchestva [Paths of Proletarian Creation]," Literaturnye manifesty : Ot simvolizma do "Oktiabria" [Literary Manifestos : From Symbolism to "October"], (M. : Agraf, 2001), 338.

12. "Puti proletarskogo tvorchestva" is composed of twelve separate "theses" (tezusy). He describes the status of the old art in thesis eleven. "The art of the past," Bogdanov writes, "just like the science of the past, contains many concealed elements of collectivism. Uncovering them, the proletarian criticism offers us the opportunity to creatively perceive the best products of the old culture in a new light and with a greatly enriched value." See Bogdanov, "Puti proletarskogo tvorchestva," 338.

13. Bogdanov, "Puti proletarskogo tvorchestva," 337.

14. See Bogdanov, "Voprosy sotsializma [Questions of Socialism]," in Raboty raznykh let [Works] (M. : Politizdat, 1990), 304.

15. During the first half of the 1920s, Lunacharskii accused Bogdanov's Proletkul't colleague, Aleksei Gastev, of being the primary propagator of this ultra-rational, "Americanist" theory of organization. It is in his 1923 essay for Izvestiia, "The New Russian Man," that Lunacharskii explicitly criticizes this theory of organization as antithetical to socialism. See Lunacharskii, "Novyi russkii chelovek," A.V. Lunacharskii : sobranie sochenenii [A.V. Lunacharskii : Collected Essays] (M. : Khudozhestvennaia literatura, 1967), 305.

16. See Lunacharskii, "The Tasks of Social-Democratic Artistic Creation," in Izbrannye stat'i po estetike [Selected Articles on Aesthetics] (M. : Iskusstvo, 1975), 62.

17. Henriette Roland-Holst was a member of the Communist Party of the Netherlands (CPN) and a delegate to the Second International. She was also a poet, journalist, and art critic, who wrote prolifically on the activities of the Bolsheviks. In "The Tasks of Social-Democratic Artistic Creation," Lunacharskii quotes her description of the function of socialist art to shore-up his own argument about the role of art, and poetry in particular, in the new social-democratic (redacted as "communist" in his 1925 version of the essay) society. "There is one quality that will be common to all proletarian art," Lunacharskii quotes Roland-Holst as having written, "light... happiness, because this art does not only, like naturalism, know and understand the things that are better studied by poetry, it knows and understands the feeling and passions that summon man to action, and also reveals the reasons for those actions [original emphasis]." See Lunacharskii, "The Tasks of Social-Democratic Artistic Creation," 57.

18. See Lunacharskii, "The Tasks of Social-Democratic Artistic Creation," 59.

19. "The depiction of struggle," Lunacharskii writes in "The Tasks of Social-Democratic Artistic Creation," "its titanic effort, its spasms, its persistence, its innovations, whether wrathful or smiling brightly, will make up the largest portion of its motifs, which will be worked over." See Lunacharskii, "The Tasks of Social-Democratic Artistic Creation," 57.

20. See A.V. Lunacharskii, Osnovy pozitivnoi estetiki [Foundations of Positive Aesthetics] (M.: Gosudarstevennoe izdatel'stvo, 1923), 131.

21. The recorded text of the lecture was reprinted in the 1926 AKhRR anthology 4 goda AKhRR. See Lunacharskii, "Iskusstvo i rabochii klass [Art and the Working Class]," 4 goda AKhRR [4 Years of AKhRR] (M. : Izdatel'stvo AKhRR, 1926), 19. 
22. In "The Tasks of Social-Democratic Artistic Creation," Lunacharskii argues that loneliness, as a state of being, is the by-product of bourgeois individualism and intellectualism. The proletarian "psychology of collectivism," on the other hand, creates a state of being, in which the members of the social body are intimately connected to one another through shared, life-affirming (zhizneradost'naia) emotional experiences. This "life-affirming continuity" exceeds the cerebral realm of thought and seeps into the realm of sensation. "The most important and valuable aspect of the proletarian outlook," Lunacharskii writes, "is, in the first place, the life-affirming continuity that distinguishes it from a patchy intellectual mosaic, and in the second place, the psychology of collectivism that distinguishes it from the intellectual individualism of loneliness." See Lunacharskii, "The Tasks of Social Democratic Artistic Creation," 61.

23. "The will of the working class," Lunacharskii wrote, "which emanates from its representatives, from the worker-peasant government, places its hopes on those artists who bear in mind three maxims : the need for a maximally comprehensive language, the need for deeply affective presence, the need to strive to be in tune with the internal harmony of the people." See Lunacharskii, "Iskusstvo i rabochii klass," 20.

24. Ibid.

25. In 1924, a short but pointed essay on the subject appeared in the fourth issue of the avant-garde journal Lef. The essay's anonymous author argued that photography documents life as it is, without the addition of subjective embellishments, and this closeness to fact that guarantees a greater impact on the spectator than painting or drawing. See Anonymous, "Fotomontazh [Photomontage]," Lef, 4 (August-December 1924) : 41.

26. Anatolii Lunacharskii, "Nasha kul'tura i fotografiia," Sovetskoe foto, 1 (April 1926) : 2.

27. "And that art of gesture," Lunacharskii writes, "the reflection of the face, the creation that emerges during staging-photography fixes all of this, and infuses everything with a new interest, because once we know that creation emerges from this work, the photograph impresses upon us a picture that remains forever, and inspires children and youth to become even more interested in the business that surround them." See Lunacharskii, "Nasha kul'tura i fotografiia," 2.

28. In the summer of 1926, Lunacharskii reiterated the argument he made in "Puti iskusstva" during his debate with the Lef theorists about AKhRR in Zhizn' iskusstva. "The artist must," he writes, "transmit reality with the full strength of his own individual perception of it, he must capture it spatially, linearly, and colorfully with maximum emotion, the artist, having discarded many details and having amplified others, gives, with maximum conviction, that internal reality, which the ordinary person does not apprehend with the naked eye, and which the artist apprehends." See Lunacharskii, “Diskussiia ob AkhRR'e," Zhizn' iskusstva, 33 (11 August 1926) : 3. 29. See Lunacharskii, "Puti iskusstva," 17.

30. See Lunacharskii, "Puti iskusstva," 17.

31. Lunacharskii notes in "Puti iskusstva" that Bogorodskii is new to both AKhRR and realist painting. He writes that the artist is not yet a master, but "an apprentice." Bogorodskii also discusses his experience, in 1925, as a newcomer to the group in his memoirs. See Lunacharskii, "Puti iskusstva," 18 ; Bogorodskii, "Kak ia pisal 'Besprizornikov," 110-111.

32. Bogorodskii, "Kak ia pisal 'Besprizornikov," 110.

33. Lunacharskii, "Puti iskusstva," 18.

34. For an assessment of the relationship between the lyrical and the haptic in Socialist Realist painting after the Cultural Revolution see Christina Kiaer, "Lyrical Socialist Realism," October, 147 (Winter 2014) : 56-77.

35. See Gilles Deleuze, Francis Bacon: The Logic of Sensation, trans. Daniel W. Smith (Minneapolis : University of Minnesota Press, 2003), 125. See also Anatolii Lunacharskii, Barukh Spinoza i burzhuaziia [Baruch Spinoza and the Bourgeoisie] (M. : Biblioteka Ogonëk, 1933); Gilles Deleuze, Empiricism and Subjectivity, trans. Constantin V.Boundas (New York: Columbia 
University Press, 2001) ; Gilles Deleuze, Spinoza : Practical Philosophy, trans. Robert Hurley (San Francisco : City Lights Publishers, 2001).

36. Lunacharskii suggests in "Puti iskusstva" that painting's haptic potential links it to poetry. He also argues that Formalist efforts to rid each form of art of the elements that seem alien to it may have unexpectedly detrimental consequences on the development of socialist art. "There are those who still consider that the majority of the theory of art should be taken over by the position that painting should be completely 'alien to literature," Lunacharskii writes, "and in this they will include the 'liberation' of the fine arts. A picture should allegedly be looked at as an aggregate of forms and colors without any relationship to the very piece of life that it reflects. This sort of instruction has an pernicious effect on art, according to our current view." See Lunacharskii, "Puti iskusstva," 14.

37. "And here," Lunacharskii emphasizes, "to be able to present, through purely spectatorial paths, some kind of social type, as if the doors have swung wide open so that you suddenly perceived, suddenly saw how the social ways became entwined, how the lines united, to create the conditions necessary to produce exactly this type-this constitutes high art [original emphasis]." See Lunacharskii, "Puti iskusstva," 18.

38. My interpretation of Chuzhak's work is indebted to Devin Fore's close reading of the poet's theoretical texts on technology and collectivity. See Fore, "The Operative Word in Soviet Factography," October, 118 (Fall 2006) : 102.

39. Nikolai Chuzhak, "Iskusstvo byta [The Art of Everyday Life]," Sovetskoe iskusstvo, 4-5 (July-August 1925) : 10.

40. For a more in-depth discussion of the evolution of Chuzhak's theory of the thing-model, which he had initially described, in the first 1925 issue of Soviet Art as the thing in the model (veshch'v modeli), see Fore, "The Operative Word in Soviet Factography," 102-103.

41. Fore describes Chuzhak's continuum theory as an "instrumental 'thingly' chain that joins together symbol and substance" and argues that it "approximates anthropologist André Leroi-Gourhan's notion of the 'operating sequence,' a 'link between technics and language' that mediates between individual memory, symbolic language, socially acquired repertoires, material instrumentation, and spatial extension." As I will show in my discussion of Lunacharskii's response to the theorists of factography, memory, both individual and collective, became the point of contention in subsequent discussions of the theory's compatibility with socialism. See Fore, "The Operative Word in Soviet Factography," 102.

42. Chuzhak, "Iskusstvo byta," 10.

43. "The idea, the plan, things, the thing," Chuzak writes, "I have already spoken several times about the continuity of this united, goal oriented process that develops from material means." See Chuzhak, "Iskusstvo byta," 10.

44. Osip Brik, "Foto-kadr protiv kartiny [The Photo-Still against the Picture]," Sovetskoe foto, 2 (1926) : 41.

45. Every photographer, Brik explains, has inherited the aspiration to become like the painter-monopolist, who works for his own economic and social gain. "The dream of every photographer," Brik writes, "to achieve in his own snapshots a 'painterly effect' comes from here." See Brik, "Foto-kadr protiv kartiny," 41.

46. Brik, "Foto-kadr protiv kartiny," 42.

47. Ibid., 41.

48. Ibid., 42.

49. Brik, "Foto-kadr protiv kartiny," 40.

50. Boris Arvatov, "Pochemu ne umerla stankovaia kartina [Why Easel Painting Is Not Dead]," Novyi lef, 1 (1927) : 41.

51. Lunacharskii and the Lef writers were well versed in one another's work. In the summer and fall of 1926, they participated in a series of debates published in journal The Life of Art. 
Lunacharskii, Arvatov, Chuzhak, the critic Emannuel' Beskin, and the AKhRR painter Evgenii Katsman, all contributed texts. See Anatolii Lunacharskii, "Diskussiia ob AkhRR'e," Zhizn' iskusstva, 33 (11 August 1926) : 34 ; "Diskussiia ob AkhRR'e," Zhizn' iskusstva, 34 (26 August 1926) : 5-6 ; “Diskussiia ob AkhRR'e," Zhizn' iskusstva, 35 (31 August 1926) : 5-6; Boris Arvatov, "Otvet t. Katsmanu [A Response to Comrade Katsman]," Zhizn' iskusstva, 34 (26 August 1926) : 7 ; Nikolai Chuzhak, "Diskussiia ob AkhRR'e : vokrug 'geroicheskogo realizma' [A Discussion about AKhRR : Regarding the Topic of 'Heroic Realism']," Zhizn' iskusstva, 36 (7 September 1926) : 5-6 ; Emmanuel' Beskin, "Ob akhrrovskom 'realizme' i ego 'prorokakh' [Regarding AKhRR's 'Realism' and 'Its Defects']," Zhizn' iskusstva, 33 (11 August 1926) : 4-5 ; Evgenii Katsman, "Pust' otvetiat [Let Them Respond]," Zhizn' iskusstva, 27 (6 July 1926) : 7-8.

52. Arvatov, "Pochemu ne umerla stankovaia kartina," 38.

53. Arvatov describes those artists who continue to paint as "bourgeois" and accuses them of running away from reality, toward the "illusionism" that defines the easel and the idealistic world of beauty, rather than the productive materials of reality. See Arvatov, "Pochemu ne umerla stankovaia kartina," 39.

54. Aratov describes mounted painting (stankovaia kartina) as having a commodity form (tovarnaia forma). This 1927 New Lef text is not the first, in which he discussed the function of the commodity or its conversion into a socialist object. As Christina Kiaer demonstrates in Imagine No Possessions, Arvatov began to formulate a theory of "comradely objects" for socialism in the early 1920s. His work had a significant impact on the development of Constructivism, and in particular on the work of Rodchenko. See Arvatov, "Pochemu ne umerla stankovaia kartina," 38 ; Kiaer, Imagine No Possessions: The Socialist Objects of Russian Constructivism (Cambridge, MA : MIT Press, 2005), 34-35.

55. See Arvatov, "Pochemu ne umerla stankovaia kartina," 39.

56. Ibid., 41.

57. "For the cultural-development of the contemporary working class," Arvatov writes, "it is obvious that can kind of mounted art (stankovism) is a feckless enemy, which like the other forms of bourgeois art (stylized posters, film, etc.), is being replaced, bit by bit, by stronger and more viable forms." See Arvatov, "Pochemu ne umerla stankovaia kartina," 39.

58. In her account of Rodchenko's work history, Margarita Tupitsyn explains that from 1928 onward the photographer produced works almost exclusively for publication in Soviet mass media periodicals. See Margarita Tupitsyn, The Soviet Photograph, 1924-1937 (New Haven : Yale University Press, 1996), 42.

59. In the Arcades Project, Walter Benjamin describes the commodity object's dazzling luster as a quality that lures the buyer to the commodity, promising, however falsely, to satisfy his needs and desires, while also concealing the alienating social relations created by capitalism. See Walter Benjamin, Walter Benjamin : Philosophy, ed. Peter Osborne (London: Taylor \& Francis, 2005) 243-244.

60. Christina Kiaer, "Rodchenko in Paris," October, 75 (Winter 1996) : 32, 35. For a more detailed history of Rodchenko's earlier work see Kiaer, Imagine No Possessions, 198-240.

61. The German-American art historian, Benjamin H.D. Buchloh first described the documentary work of Rodchenko and other avant-garde artists as "factography." The term has since been integrated into the American and European art historical canon. See Buchloh, "From Faktura to Factography," October, 30 (Fall 1984) : 84.

62. See Fore, "The Operative Word in Soviet Factography," October, 118 (Fall 2006) : 101.

63. Ibid., 119.

64. Ibid., 105.

65. Sheila Fitzpatrick, The Cultural Front : Power and Culture in Revolutionary Russia (Ithaca : Cornell University Press, 1992), 132-133. 
66. The Communist Academy evolved from the Socialist Academy of Social Science, which was established in Moscow in 1918 as an international center for socialist thought. Members of the Socialist Academy included Lunacharskii, Trotskii, Nikolai Bukharin, Rosa Luxemburg, and Karl Kautsky. The Academy was renamed the Communist Academy in 1924, in order to obscure its social-democratic roots. In 1926 it was brought under the control of the Central Committee. For more on the history of the Communist Academy see L.A. Kogan, "Na podstupakh k sovetskoi filosofii (pervyie "sverdlovtsy", "sots. akademiia", "ikapisty") [Approaching Soviet Philosophy (the first "Sverdlovists," the "Socialist Academy," and the "Ikapists")]," Voprosy filosofii, 5, (2002) : 112-140.

67. The German-born communist activist Al'fred Kurella served, together with the Hungarian émigré Ivan Matsa, Aleksei Mikhailov, and Pavel Novitskii, as one of the group's four primary theorists. In his 1928 article "Regarding the Slogan 'Proletarian Art," Kurella accused the New Lef writers of deemphasizing art in favor of an exclusive focus on "the organization of material life itself." On the other hand, he accused AKhRR of fetishizing the easel object, rather than trying to work out the "fundamental problems of painting." See Al'fred Kurella, "O lozunge 'proletarskoe iskusstvo' [Regarding the Slogan 'Proletarian Art']," in Iskusstvo v SSSR i zadachi khudozhnikov : disput v kommunesticheskoi akademii [Art in the USSR and the Tasks of Artists : A Dispute at the Communist Academy] (M. : Izdatel'stvo kommunesticheskoi akademii, 1928), 43, 49 ; 1928 declaration of the Group "October," in Ivan Matsa, ed., Sovetskoe iskusstvo za 15 let [15 Years of Soviet Art] (M.-L. : IZO-GIZ, 1933), 608.

68. This is not surprising given that many of the group's artist-members, including Sergei Eisenstein, Aleksei Gan, and Aleksandr Rodchenko had been associated, in the late teens and early 1920s, either with Proletkul't itself or with the first wave of Proletkul't influenced Lef theory.

69. "Our time," writes Mikhailov, "demands not still life-ness (natiurmortnost'), but a living life, which does not tear man away from nature or things, but reveals their interplay and unity. But mounted (stankovaia) painting cannot simultaneously show a landscape and people and things in the continuum of their existence and activity." See Aleksei Mikhailov, "Kino i zhivopis'," in Iskusstvo v SSSR i zadachi khudozhnikov : disput v kommunesticheskoi akademii, 67.

70. "Film," Mikhailov writes, "does not only speak in a language of collective images, it also makes them visible to the collective." See Mikhailov, "Kino i zhivopis'," 69.

71. Kurella, "O lozunge 'proletarskoe iskusstvo'," 45.

72. In the same year that Kurella described his objections to New Lef theory, Lunacharskii also raised a similar concern about the group's call for total industrialization. "We have very often confused theoretical and philosophical idealism," Lunacharskii wrote, "with a practical idealism. For example, the well-known poet Tret'iakov recently declared that we must declare war against pathos and place all our stock in 'hardheadedness'." Here Lunacharskii describes Tret'iakov's theory of literature as a "practical idealism" in order to suggest that the Lef writers have failed to recognize the industrial means as material elements with a particular history and ideology. Instead, they have accepted them as the new ahistorical "nature" (natura), to use Brik's word. He also suggests that despite their discussions of the importance of sensation, in their pursuit of "hardheadedness" they have de-emphasized the body. See Lunacharskii, "Etika i estetika Chernyshevskogo pered sudom sovremennosti [The Ethics and Aesthetics of Chernyshevskii before the Court of Contemporaneity]," in A.V. Lunacharskii : Sobranie sochinenii, tom 7, 543.

73. "We must explain," Kurella writes, "why and for what reason we have to approach the artistic formulation of things according to a plan, scientifically, why we want to achieve this through a planned out, organized approach." See Kurella, "O lozunge 'proletarskoe iskusstvo'," 45.

74. Kurella, "O lozunge 'proletarskoe iskusstvo'," 45.

75. "Nonetheless," Kurella explains, "the point is this: regarding painting, sculpture, architecture, furniture, etc., regarding the materialistic production of art, we must demand that 
proletarian artists approach their own work consciously-scientifically, just as they do organizationally, so that they build, in a way that is planned, beginning with the choice of the subject, proceeding with the formulation of the topic, the composition, and ending with its faktura, just as we demand this from any member of the proletarian leadership at the factory or any institution." See Kurella, "O lozunge 'proletarskoe iskusstvo'," 44.

76. Declaration of the Group "October," Sovetskoe iskusstvo za 15 let, 608.

77. The October group listed "architecture, painting (zhivopis'), sculpture, graphic works, the industrial arts, photography, cinematography, etc." as the forms of art they considered best suited to a collective, proletarian society. Aleksei Mikhailov was quick to point out, however, that painting must be implemented in the form of large-scale frescoes, rather than easel objects. The fresco, he argued, was more likely to expose the inherent connections between the spectator and the material, rather than contain and conceal them the way an easel painting does. See Declaration of the Group "October," Sovetskoe iskusstvo za 15 let, 608; Aleksei Mikhailov, "Zakliuchitel'noe slovo A. Mikhailova [A. Mikhailov's Closing Word]," Iskusstvo v SSSR i zadachi khudozhnikov,108.

78. See AKhR, "Vtoraia deklaratsiia Assotsiatsii khudozhnikov revoliutsii [The Second Declaration of the Association of Artists of the Revolution]," Sovetskoe iskusstvo za 15 let, 356.

79. The AKhR painter Viktor Perel'man writes that the younger generation of AKhR artists, who had already formed their own section within the group -the Organization of the Youth of AKhRR (OMAKhRR)-became interested in some of the same imperatives as the "leftists" from the October Group, including the "organization of everyday life" through the "spatial arts (architecture, workers' clubs, and mass celebrations), and sought ways to unify realist painting with these means. See Viktor Perel'man, "Iskusstvo v massy : 10 let akhrrovskogo dvizheniia (1922-1932) [Art to the Masses: 10 Years of AKhRR's Activities (1922-1932)]," Assotsiatsiia khudozhnikov revoliutsionnoi Russii [The Association of Artists of Revolutionary Russia] (M. : Izobrazitel'noe iskusstvo, 1973), 113.

80. Viktor Perel'man wrote in the first issue of Art to the Masses, that fine art would play a significant role in the Cultural Revolution "only when it learns to emotionally infect the working class spectator with ideas and feelings of October. Now more than ever, we must recall the words of Chardin: 'One must render not with paint, but with feeling." See Perel'man, "Puti AKhR [AKhRR's Paths]," Iskusstvo v massy 1-2 (1929), 22.

81. In 1930, the Museum of the Revolution, AKhR's most significant institutional patron, published a catalogue of the postcards based on the group's work and the work of the nineteenth century Wanderers, who were considered the group's predecessors. "The series may serve," the catalogue's author wrote, "as a vivid aid in the absorption of the history of the revolution and in the study of the contemporary development of socialism." See Anonymous, Katalog khudozhestvennykh otkrytykh pisem [Catalogue of Art-Postcards] (M. : Muzei revo-liutsii SSSR, 1930), 2.

82. I do not mean to suggest here that the early Soviet public experienced painterly materiality and developed a memory of it only through its exposure to figurative realist paintings produced after 1917. Indeed, many members of the broader Soviet public would have had access to these images only through their reproductions. I want to suggest that the Soviet experience and memory of painterly materiality has a long prehistory, which begins with the apprehension and circulation of Orthodox icons and their hand-made reproduction for the home.

83. As Ekaterina Degot has shown, postcard reproductions of paintings remained a central component of Soviet visual culture after World War II. See Ekaterina Degot, "The Copy Is the Crime : Unofficial Art and the Appropriation of Official Photography," in Diane Neumaier, ed., Beyond Memory: Soviet Nonconformist Photography and Photo-Related Works of Art, (New Brunswick : Rutgers University Press, 2004), 108. 


\section{RÉSUMÉS}

Dans le domaine culturel, la période comprise entre la révolution d'Octobre et la mise en œuvre du Premier Plan quinquennal a été marquée par une série de vifs débats publics sur la fonction des arts visuels et des média dans la toute nouvelle société socialiste. Des théoriciens éminents, tel le commissaire du peuple à l'Instruction publique Anatolij Lunačarskij, et des écrivains affiliés au journal Lef, tels Boris Arvatov et Sergej Tret'jakov, participaient à ces débats au même titre que des artistes modernistes et des peintres réalistes. La photographie était un thème central et, en 1925, la question d'évaluer comment les avancées technologiques en matière de photographie ou de toute autre forme de reproduction mécanique pouvaient changer la nature du visuel s'était imposée comme la plus pressante. Alors que dans tous les débats les factions participantes reconnaissaient l'importance de la photographie, elles admettaient aussi que les composants matériels de la peinture, notamment les couleurs et la texture de la surface, demeuraient essentiels au développement de relations socialistes de bonne camaraderie. Cet article apporte pour la première fois un éclairage sur les aspects de la jeune pensée soviétique sur l'esthétique et la communication qui conduisirent à établir fermement la peinture comme un média visuel essentiel au socialisme. Il démontre en particulier que la matérialité de la peinture et ses traces étaient liées à l'activation et à la transmission des sensations du corps, lesquelles étaient considérées comme nécessaires à la formation de connexions socialistes.

In the cultural sphere, the period between the October Revolution and the initiation of the first five-year plan was marked by a series of heated public debates about the function of visual art and media in the new socialist society. Prominent theorists, including the Commissar of Enlightenment, Anatolii Lunacharskii, and writers associated with the journal Lef, such as Boris Arvatov and Sergei Tret'iakov, participated in these debates, as did modernist artists and realist painters. Photography was a central theme, and by 1925 the question of how the advances in photographic and other forms of mechanical reproduction were changing the nature of the visual had emerged as the debates' most pressing problem. While all of the debates' contending factions recognized the significance of photography, they also agreed that the material components of painting-particularly color and surface texture-remained essential to the development of comradely socialist relations. This article brings to light for the first time the aspects of early Soviet thought on aesthetics and communication that led to the firm establishment of painting as a visual medium essential to socialism. It demonstrates in particular that the materiality of painting and its traces were linked to the activation and transmission of the sensations of the body, which were considered necessary for the formation of socialist connections. 


\section{AUTEUR}

\section{ANGELINA LUCENTO}

National Research University-Higher School of Economics, International Center for the History and Sociology of World War II and Its Consequences, Northwestern university, IL, ang

elinalucento2012@u.northwestern.eduEN 